\title{
REGULATION \& MANAGED CARE: AN EMPIRICAL EXAMINATION OF STATE OB/GYN LAWS
}

Brian Veronda

\begin{abstract}
Since 1995, states have played an increasingly active role as regulators of managed care health plans. However, there is little consistency from state to state in the laws that govern managed care plans. This paper analyzes this inconsistency within the framework of the economic and political theories of regulatory choice. An empirical model is developed to test whether these theories can explain the presence of two laws regulating women's access to obstetrician-gynecologists (OB/GYNs). The results suggest that these theories together do help to clarify why certain states enacted the regulations. The regulations were more likely to be present in states with a relatively high number of OB/GYNs and female legislators, and Democratic control of government.
\end{abstract}

The 1990s have witnessed managed care's transformation from a burgeoning, yet small, segment of the health insurance industry to a dominant force that has changed the entire industry. Most health care analysts attribute the rise of managed care to the skyrocketing health care costs of the 1970 s and 1980s. Managed care appealed to health insurance purchasers-mostly employers-because it promised lower insurance premiums. Indeed, the rate of health care inflation has fallen steadily in conjunction with increased managed care enrollments. ${ }^{1}$ Despite reduced costs, dissatisfaction with managed care appears high. For example, a survey conducted by Blendon et al, ${ }^{2}$ found that 45 percent of respondents indicated that they believe that managed care has lowered the quality of health care in America. Fifty-four percent reported that they anticipate that the trend toward managed care would lower the quality of care in the future.

The government has responded to this discontent with a torrent of managed care legislation and regulation proposals. President Clinton's unsuccessful 1994-95 reform plan was but the first salvo in the government's regulatory efforts. The president's plan, however, was not just an attempt to ameliorate concerns with managed care-it sought to restructure the entire health insurance industry. The complexity and scope of the plan are often cited as reasons for its failure. ${ }^{3}$

A significant consequence of failed national health care reform was the shift in emphasis from the federal government to the states - those who sought federal regulation looked to the states as the principle health care policymakers. ${ }^{4}$ States have responded with a profusion of managed carerelated proposals. Bodenheimer, ${ }^{5}$ for example, estimated that state legislatures introduced over 1,000 bills in 1996 alone. Unlike President Clinton's reform plan, state proposals tend to address specific objectives, such as mandating a minimum level of quality (e.g., maternity lengthof-stay laws) or facilitating access to specialty care. The upshot of the states' decision to regulate specific managed care practices is that there is little consistency from state to state in the laws governing managed care plans.

What accounts for the inconsistency of state managed care laws? Are there factors we can identify that might explain why certain states passed a regulation, while other states did not? The intent of this paper is to explore these questions within a framework of regulatory choice theories. Theories of regulatory choice seek explanations for the existence of regulation (or deregulation). Although analysts have used these theories to examine regulatory action in other industries, managed care analysts have seldom used this framework. In fact, Ohsfeldt's et al.'s $\mathrm{s}^{6}$ investigation of state "anywilling-provider" laws was the only managed care study found that analyzed a particular managed care regulation in the context of regulation theory. However, their study specifically tested Becker's ${ }^{7}$ model of interest group competition as it related to the economic theory of regulation.

Brian Veronda is pursuing a Master's of Public Administration at The George Washington University. He received a Bachelor of Arts in Economics from the University of Arizona in 1994.

Policy Perspectives, Fall 1999 (Volune 7 Number 1) (6) 1999 The George Washington University 
This paper incorporates both the economic and political theories into the same empirical model. ${ }^{8}$ Specifically, an empirical model is developed to test whether the competing political and economic theories of regulation help to describe the presence of two laws regulating women's access to obstetrician-gynecologists (OB/GYNs). The results suggest that the regulation theories do help us to understand why states enact regulations. However, neither theory provides a fuller account than the other.

\section{Regulation in Perspective}

Regulation is typically characterized as either "economic" regulation or "social" regulation. Each type of regulation has its own distinct goals and objectives.

\section{Economic Regulation}

Economic regulation "governs prices, output, terms of competition, and entry/exit." Natural monopolies, such as electric utilities, are a common justification for economic regulation because the marginal cost of production decreases as more units are produced. Most economists would argue that the economically efficient solution to the problem of natural monopolies is to allocate monopoly power to one firm and regulate prices to prevent monopolistic pricing. ${ }^{10}$

"Moral hazard" is a second justification for government price regulation. Moral hazard exists when someone other than the consumer purchases a good for that consumer. Health insurance is the classic example of moral hazard. Health insurance significantly lowers the consumer's out-of-pocket health care costs and provides an incentive to over-consume health care. ${ }^{11}$ In fact, managed care gained prominence, in part, because it effectively addressed the moral hazard problem. In traditional health insurance, the "producer" (physician) and "consumer" (patient) do not bear any financial burden of consumption; health insurance plans simply reimburse the physician or patient for services rendered or received. Managed care utilizes a variety of mechanisms that force physicians to share in the financial risk of the care that they provide.

Finally, economic regulation seeks to ensure that markets remain competitive. Competitive markets are a particular concern in the managed care industry. Over the past few years, the industry has experienced a wave of mergers and consolidations. The result is a rapidly transforming industry shaped by horizontal consolidation and vertical mergers, affiliations, and strategic alliances. In 1994, 43.2 percent of managed care enrollees were enrolled in the five largest plans; 58.3 percent were enrolled in the ten largest plans. By 1997, these concentration ratios increased to 49.9 percent and 67.2 percent, respectively. ${ }^{12}$ As HaasWilson and Gaynor ${ }^{13}$ note:

The key questions are to what extent these changes enhance efficiency and quality, and to what extent they facilitate collusion and market power. If competition is lessened, is there a significant loss of social welfare in the form of higher prices, lower quality, restraints on consumer choice, or less technological innovation? And if so, what is the appropriate antitrust policy?

\section{Social Regulation}

Social regulation is "concerned with the externalities and social impact of economic activity." 14 In other words, social regulations address the by-products of competition and the pursuit of profits. ${ }^{15}$ Most managed care regulations are social regulations; they attempt to "protect" patients from profit-seeking managed care firms.

Recent federal managed care regulation has focused on social regulation legislation. For example, the $1996 \mathrm{Health}$ Insurance Portability Act set national standards for the portability of health insurance for individuals moving from one employer to another. The Newborns' and Mothers Health Protection Act addressed the issue of "drive-through deliveries" by requiring insurers to cover a minimum 48-hour length of hospital stay for women giving birth. Currently, Congress is debating various versions of a "Patients' Bill of Rights." These bills seek to set quality standards, provide more flexible access to specialists, and, in some versions, allow consumers to sue health maintenance organizations (HMOs) ${ }^{16}$

States have also passed a wide variety of managed care regulations. These laws primarily fall into the social regulation category. Marsteller and Bovbjerg ${ }^{17}$ categorize state "patient protection" laws by four sources of concern about managed care. First, states have regulated managed care physician networks by either mandating who managed care firms can contract with (e.g., "any-willing-provider" laws) or identifying conditions that allow patients to seek care outside a network. Second, states have mandated the coverage of certain benefits, such as emergency room care or experimental treatments. Third, states have targeted the methods some managed care firms use to manage health care utilization (e.g., clear definitions of medical necessity). Finally, states have addressed the financial incentives some managed care firms provide physicians to limit care. 
Regulation targeted at women's health issues is also a criti$\mathrm{cal}$ area of managed care regulation. Some of these regulations target specific procedures. Thirty states require coverage of reconstructive breast surgery; forty-eight mandate breast cancer screenings; twenty-two regulate cervical cancer screenings; and coverage of contraceptives is mandated by fourteen states. ${ }^{18}$ Other regulations focus on providing women access to specialists-especially $\mathrm{OB} /$ GYNs. Thirty-three states afford women access to $O B /$ GYNs, while eighteen states allow OB/GYNs to serve as primary-care physicians.

\section{Theories of Regulatory Choice}

The previous section outlined the two types of regulation. Theories of regulatory choice seek to explain why governments enact these regulations. There are three general theories of regulatory choice: public interest theory, economic theory, and political theories.

\section{Public Interest Theory}

The public interest theory asserts that regulations exist to address the market's failure to produce economically or socially optimal outputs. For example, Arrow ${ }^{19}$ notes that health care markets are characterized by a number of imperfections that differentiate them from "standard" markets (e.g., moral hazard and asymmetry of information between physicians and patients). Advocates of a single-payer health system (that is, government funded) have argued that market failures prohibit an economically efficient health care system. Viewed in terms of social regulation, the public interest theory would assert, for example, that 48 -hour mandatory hospital stay laws were passed because managed care firms were rushing women out of the hospital ("drivethrough deliveries"). Legislation was seen as an effort to mandate a certain level of quality care.

\section{Economic Theory}

The economic theory of regulation-led by Stigler ${ }^{20}$ and Peltzman ${ }^{21}$-presumes that politicians (like everybody else) are self-interested utility maximizers who are solely concerned with reelection. The political process is simply a competition among interest groups to capture the benefits (or "rents") afforded by politicians. The "winners" are the groups that can provide politicians with the necessary tools-for example, money and votes-needed to ensure continued reelection. This theory hypothesizes that small groups with large per capita interests are most often the winners of this competition. Large, diffuse groups, such as consumers, have difficulty effectively organizing because each individual's benefit is small; indi- viduals have an incentive to free ride off of the action of the others in the group. ${ }^{22}$ Additionally, the influence of interest groups on politicians is not fixed-politicians change alliances based on the relative power of interest groups over time.

Recall the 48-hour mandatory hospital stay law. The economic theory would presume that the regulation was passed because the parties with the largest per capita interestprobably OB/GYNs and hospitals-were better organized and better equipped to pressure and reward politicians.

\section{Political Theories}

Political theories of regulatory choice criticize both the public interest theory and economic theory as simplistic and incomplete. These theories assert that it is unrealistic to reduce policy decisions solely to economic factors or interest group bargaining. ${ }^{23}$ There are several political theories.

Derthick and Quirk ${ }^{24}$ offer a "politics of ideas" model, which describes how politicians and policy can converge around a set of ideas. They found that, in certain industries, deregulation occurred despite well-organized, politically powerful interest groups that had an interest in maintaining regulation. Derthick and Quirk attributed the success of deregulation to politicians using influential academic critiques of regulation to foster their own political agendas, to appeal to a broad range of constituents, and to support their own ideology.

Wilson ${ }^{25}$ suggests a second model of "entrepreneurial politics." Wilson described a skilled entrepreneur as one who can

...mobilize latent public sentiment (by revealing a scandal or capitalizing on a crisis), put the opponents of the plan publicly on the defensive (by accusing them of deforming babies or killing motorists), and associate the legislation with widely shared values (clean air, pure water, health, and safety).

Indeed, managed care is often cast as the villain of the health care system. Managed care "horror stories" are ubiquitous in the media, political speeches, and reform efforts.

In sum, the theories of regulatory choice posit explanations for why regulation occurs from three different perspectives of policymaking and the behavior of politicians. The public interest theory makes the assumption that policymakers can identify and agree that markets are producing economi- 


\begin{tabular}{|c|c|c|c|}
\hline \multicolumn{4}{|c|}{$\begin{array}{l}\text { Table } 1 \\
\text { States Passing OB/GYN-related Laws }\end{array}$} \\
\hline 1994 & 1995 & 1996 & 1997. \\
\hline Maryland & Connecticut & Alabama & Arkansas \\
\hline \multirow[t]{11}{*}{ New York } & Florida & Colorado & Delaware \\
\hline & Louisiana & Georgia & Idaho \\
\hline & Mississippi & Indiana & Minnesota \\
\hline & North Carolina & Illinois & Missouri \\
\hline & Oregon & Maine & Montana \\
\hline & Utah & Nebraska & New Jersey \\
\hline & Washington & Virginia & New Mexico \\
\hline & & West Virginia & Nevada \\
\hline & & & Rhode Island \\
\hline & & & Texas \\
\hline & & & Vermont \\
\hline
\end{tabular}

cally or socially sub-optimal outputs. This seems an unrealistic assumption. Take the debate over President Clinton's health care reform plan as an example. Advocates of the President's plan argued that the health care industry was riddled with pervasive market failure that necessitated a regulatory remedy. Others, however, questioned whether the market had indeed failed; they believed that if problems did exist, the market would ultimately find the most efficient solution.

The economic and political theories appear to offer more realistic assumptions of regulatory politics. Consequently, the next section will empirically test these two competing theories.

\section{Model and Hypotheses}

Managed care firms typically require enrollees to obtain a referral from a primary care physician prior to visiting a specialist. Most managed care firms do not consider $\mathrm{OB} /$ GYNs to be primary care physicians. As a result, women must first see an approved primary care physician prior to seeing a specialist even though most women would rather simply visit the OB/GYN. Recently, many states have begun to pass regulations that provide women with some form of direct access to $O B / G Y N$ services. Legislatures are using two approaches to provide this access: (1) not
Table 2

States Passing Direct Access to OB/GYN Laws

\begin{tabular}{|llll|}
\hline 1994 & 1995 & 1996 & 1997 \\
Maryland & Connecticut & Alabama & Arkansas \\
& Florida & Colorado & Delaware \\
& Louisiana & Georgia & Idaho \\
& Mississippi & Illinois & Minnesota \\
& North Carolina & Maine & Missouri \\
& Oregon & Virginia & Montana \\
& Utah & West Virginia & Nevada \\
& Washington & & New Mexico \\
& & & Rhode Island \\
& & & Vexas \\
& & &
\end{tabular}

requiring women to first obtain a referral from a primary care physician and (2) allowing women to designate $\mathrm{OB} /$ GYNs as primary care physicians. ${ }^{26}$

This section estimates a model of the $O B / G Y N$ regulations within the framework of the economic and political theories of regulatory choice. First, it explores the passage of either of the two regulations (i.e., either the direct-access regulation or the regulation allowing women to designate an $O B / G Y N$ as a primary care physician). Second, it examines the specific regulation allowing women to bypass their primary care physician in favor of an OB/GYN. ${ }^{27}$ Tables 1 and 2 list the states that have passed these regulations.

The data are a pooled time series for all fifty states from 1994-1997. Each regulation represents a separate dependent variable. Both dependent variables are binary $(0$ or 1$)$ indicating the presence or absence of the regulation. The explanatory variables are lagged one year (e.g., the year 1995 is analyzed using $1994 \mathrm{data}){ }^{28}$ The model's specification is as follows:

$$
\begin{aligned}
& \mathrm{OB} / \mathrm{GYN} \mathrm{REG}=\alpha+\beta_{1} \mathrm{OB} / \mathrm{GYN}+\beta_{2} \mathrm{PCP} \\
& +\beta_{3} \mathrm{HMO}+\beta_{4} \mathrm{LRGEMP}+\beta_{5} \text { FEMLEG }+ \\
& \beta_{6} \mathrm{DEMGOV}+\beta_{7} \text { FEMPOP }+\varepsilon
\end{aligned}
$$


Where:

$\mathrm{OB} / G Y N \mathrm{REG}=0$ if state has not adopted the regulation or 1 if state has adopted the regulation

$\mathrm{OB} / \mathrm{GYN}=\mathrm{OB} / \mathrm{GYN}$ ser 100,000 (Bureau of Health Professionals, Area Resource File, February 1999)

$\mathrm{PCP}=$ Primary Care Physicins per $100,000(\mathrm{Bu}-$ reau of Health Professionals, Area Resource File, February 1999)

$\mathrm{HMO}=\mathrm{HMO}$ enrollment as a percentage of state population (Bureau of Health Professionals, Area Resource File, February 1999)

LRGEMP $=$ Percent of state business establishments with $>1,000$ employees (Bureau of the Census <www.census.gov>)

FEMLEG = Female state legislators as a percentage of total state legislators (Urban Institute <www.urban.org>)

DEMGOV $=0$ to 3 depending on Democrat control of state house, senate, or governor (Urban Institute <www.urban.org $>$ )

FEMPOP $=$ Percentage of voting-age women within a state (Bureau of the Census, $<$ www.census.gov>)

\section{Hypotheses and Measures - Economic Theory}

Economic theories of regulatory choice assert that politics is a competition among interest groups, with the most powerful interest group getting the policy it wants. In the case of the OB/GYN regulations, we can test this assertion by measuring the influence of the groups favoring and opposing the laws. Interest group strength is difficult to measure. Ideal data would identify how and how much pressure the respective interest group puts on state legislators-for example, data on lobbying efforts or campaign contributions. Unfortunarely, this kind of data either does not exist or is not readily available. Consequently, this model uses proxy measures to indicate interest group strength. Note that Ohsfeldt et al. ${ }^{\text {" }}$ used a similar specification.

$\mathrm{OB} / \mathrm{GYN}$ s were the most likely interest group to favor these regulations because the regulations clearly benefit $\mathrm{OB} /$
GYNs by either expanding their patient base or removing an obstacle that prevents them from seeing more patients. The number of $O B / G Y N$ s per 100,000 is used to measure the interests of $\mathrm{OB} / \mathrm{GYNs}$. So, if the economic theory holds true, we would anticipate OB/GYN interests to be positively associated with the passage of the two regulations.

Three groups were most likely to oppose the two regulations. First, primary care physicians would oppose the regulations because the regulations could reduce their patient volume. ${ }^{\text {,t }}$ The requirement that women see a primary care physician is, in a sense, a barrier to entry for specialty physicians like OB/GYNs. Primary care physicians presumably do not want this shield from competition removed. The interests of primary care physicians are measured as the number of primary care physicians per 100,000 people.

Managed care firms are hypothesized to oppose the $\mathrm{OB} /$ GYN laws. The requirement that enrollees see a primary care physician prior to visiting a specialist is one of the main tenets of managed care (especially HMOs). Opponents of direct-access laws argue that these laws impair the managed care organization's ability to contain costs. ${ }^{31}$ Managed care opposition is measured by the percentage of a state's population enrolled in an HMO. HMOs, rather than all managed care types, were used for two reasons. First, HMOs are most likely to impose the primary care physician on enrollees-preferred provider organizations (PPO) and point-of-service plans (POS) have more flexible network policies. Second, this data was most readily available.

Finally, employers are expected to oppose the OB/GYN regulations because of the prospects of increased premiums. Indeed, employers began contracting with managed care plans because of their ability to offer lower insurance premiums. ${ }^{32}$ The percentage of business establishments with over 1,000 employees measures the opposition of employers. The 1,000-employee threshold was used because (a) large employers are much more likely to offer health insurance than smaller employers and (b) large employers-it is assumed-are better equipped to organize than smaller employers. Since the number of small employers in a state far outnumber the number of large employers, small employers are susceptible to the free rider problem.

\section{Hypotheses and Measures - Political Theories}

The model estimates the impact of three political variables on presence of the two OB/GYN regulations. The first measures the extent of Democratic control of each state government, presuming thu humocrats are more likely 
to support the $O B / G Y N$ regulations than are the Republicans. Recent debate in Congress over the "Patients' Bill of Rights" appear to support this presumption. The Democratic version of the bill includes language that allows women to choose an OB/GYN as a primary care physician, while the Republican version omits it. ${ }^{33}$ The number of policymaking institutions (house, senate, and governor) that are controlled by the Democratic Party measures the partisan control of state government. The number ranges from 0 to 3 , with 3 indicating total Democratic control. ${ }^{34}$ It is predicted that the regulations are more likely to pass as this measure approaches 3 .

The number of women legislators serving within each state is the second political measure. It is estimated that the more women who serve in a state legislature, the more likely that a state will pass the regulation. This measure was included for two related reasons. First, the personal experiences of policymakers often serve as an important catapult for issues to reach the legislative agenda. ${ }^{35}$ Second, it is assumed that women are more likely to sympathize with women's health issues than are men. For example, in their study of the certain state 48-hour hospital stay laws, Declercq and Simmes ${ }^{36}$ noted that "all six New England state legislative sponsors were women and mothers who strongly believed that a woman should have the option of recuperating in the hospital." This variable is measured by the percentage of women serving within each state legislature.

The final political variable is the percentage of voting-aged women within each state. This measure is included for two reasons. First, this percentage might influence a legislator's decision to use $O B / G Y N$ issues to practice "entrepreneurial politics." Legislators can use the negative image of managed care firms to appeal to women as protectors of their health. Second, much has been made of the "gender gap" between Democrats and Republicans exposed during the

Table 3

Expected Direction of Association, Logistic Regression Coefficients of Explanatory Variables of OB/GYN-related Regulations and "Direct-Access" Regulations, 1994-1997 (n=200)

\begin{tabular}{|c|c|c|c|}
\hline & $\begin{array}{l}\text { Expected Direction of } \\
\text { Association }\end{array}$ & $\begin{array}{l}\text { Coefficents: Both Laws } \\
\text { (standard errors) }\end{array}$ & $\begin{array}{l}\text { Coefficients: Direct Access } \\
\text { (standard errors) }\end{array}$ \\
\hline PCP Rate & Negative & $\begin{array}{c}-0.018 \\
(0.030)\end{array}$ & $\begin{array}{l}-0.026 \\
(0.0289)\end{array}$ \\
\hline OB/GYN Rate & Positive & $\begin{array}{l}0.250^{* *} \\
(0.121)\end{array}$ & $\begin{array}{l}-0.026 \\
(0.0289)\end{array}$ \\
\hline Large Employer & Negative & $\begin{array}{l}-.306 \\
(7.802)\end{array}$ & $\begin{array}{l}-3.423 \\
(8.149)\end{array}$ \\
\hline Female Legislators & Positive & $\begin{array}{l}0.062^{*} \\
(0.038)\end{array}$ & $\begin{array}{l}0.061 \\
(0.039)\end{array}$ \\
\hline Female Population & Positive & $\begin{array}{l}0.124 \\
(0.205)\end{array}$ & $\begin{array}{l}0.118 \\
(0.212)\end{array}$ \\
\hline Log-likelihood & & -65.376 & -62.735 \\
\hline Dependent Variable Mean & & 0.183 & 0.164 \\
\hline
\end{tabular}


1992 and 1996 presidential elections. ${ }^{37}$ This gender gap might make members of both parties more sensitive to women's issues. It is hypothesized that the percentage of voting-age women is positively associated with the passage of the $O B / G Y N$ regulations.

\section{Results}

The model is estimated using logistic regression because the dependent variables are binary. ${ }^{38}$ Logistic regression estimates the relative probability of the presence or absence of the regulations as a function of the estimated parameters $\left(\beta_{i}\right)$. Table 3 presents the results.

Overall, the model fits reasonably well. First, the overall model for both regressions is statistically significant at the 0.01 level (either law: $p=0.008$; direct-access: $p=0.0026$ ). Second, all the explanatory variables are associated with the dependent variables in the expected direction. That is, $\mathrm{OB} /$ GYNs, Democratic control of government, female legislators, and female population are positively associated with the regulation. On the other hand, primary care physicians, HMO penetration, and large employers are negatively associated with the regulation.

The only statistically significant economic variable in either regression was the $O B / G Y N$ rate $(p<0.05)$. This result suggests that, all things being equal, the more OB/GYNs who operate in a state, the higher the probability a state will adopt the $\mathrm{OB} / \mathrm{GYN}$ regulations. In fact, each additional $\mathrm{OB} / \mathrm{GYN}$ per 100,000 increases the odds ${ }^{39}$ of having regulation by 28.4 percent; this measure increases the odds of a state adopting the direct-access law by 32.1 percent. Recall the economic theory of regulation presumes that small groups with vested interests are more likely to win an interest group competition. Based on this result, the economic theorists would posit that the OB/GYNs not only had the most vested interests but were also the most organized. The interest groups opposing the laws-primary care physicians, HMOs, and large employers-were perhaps unable to effectively oppose the regulations because their interests were diffuse.

Two political variables were statistically significant. The first-female legislators - was significant for the either law regression but not the direct-access regression $(p<0.10)$. Democratic control of government was statistically significant in both regression runs ( $\mathrm{p}<0.01$ for both regressions). Again, these results suggest that, all things being equal, in states with more female legislators and more Democratic control, there exists a higher probability that the regula- tions will pass. The Democratic measure provided the most notable result-states completely controlled by the Democratic Party ( 3 on the scale) were more than 78 percent more likely to pass the regulations than were states with no Democratic control (0 on the scale).

It is especially interesting to note the significance of the two political variables in light of the economic theory of regulation. None of the economic models account for factors such as ideology, partisanship, or personal experience. Instead, the theories generally view politics as a production function, with interest group pressure acting as the only input. The political theories-which argue that the economic theory is simplistic - view the political process as much more complex. The fact that both economic and political variables were statistically significant lends support to the political view.

\section{Conclusion}

The purpose of this paper was to explore the reasons why some states pass managed care regulations, while other states do not. The study was conducted by analyzing two state $O B / G Y N$ laws within the framework of the economic and political theories of regulation. Based on this study, both theories provide some explanation of the variance in state laws.

The economic theory contends that concentrated groups that have large vested interests are most likely to win a regulatory battle. In this study, states with higher proportions of OB/GYNs were more likely to pass the regulations. The fact that the OB/GYN measure was the only statistically significant explanatory variable lends support to this theory. Given the interest groups favoring and opposing the regulations, $O B / G Y N$ s are far and away the most concentrated. Moreover, the OB/GYNs have a powerful interest groupthe American College of Obstetricians and Gynecologiststhat lobbies each state legislature. "On the other hand, primary care physicians - who do not have a similar organization-are susceptible to the free rider problem. Certainly business and managed care have their respective interest groups, but it is unclear how organized these groups are at the state level. Assuming that these interest groups are not well organized at the state level, the economic theory would predict that these groups would have difficulty competing against the more organized OB/GYNs. The results of the analysis seem to support this theory.

An alternative reason why managed care was unable to effectively oppose the regulations is, perhaps, that man- 
aged care organizations wanted the regulations. For years, managed care organizations grew enrollments primarily by cutting the premiums of employers who contract with the plans. Now that managed care is so widespread, many are evaluating these plans in terms of quality, not just cost. In light of President Clinton's comprehensive reform attempt, coupled with the increasingly negative view of managed care by the general public, some analysts assert that managed care seeks regulation as a form of preemption. ${ }^{41}$ In other words, managed care might welcome regulations now either to avoid more drastic regulation in the future or to quiet some of the criticism that would potentially lead to new entrants into the market.

Proponents of the political theory can find evidence from this study that their theory is the most complete. The fact that female legislators impacted the passage of the regulations bolsters the "entrepreneurial politics" theory. Additionally, the variable that had the most significant effect on the passage of the regulations was Democratic control of state government. This result appears to indicate that, contrary to the economic theory, partisanship and ideology are important factors in policymaking. However, the list of states that passed the regulations (see Table 1) might somewhat temper the real impact of ideology or partisanship. This list comprises a surprising number of Southern states. Although Democrats traditionally control these states, they are not typically "liberal" states. Perhaps there are other factors other than politics at work in these states. In a study of "any-willing-provider" laws, Marsteller et al. ${ }^{42}$ concluded that some states with low managed care penetration pass laws in anticipation of future managed care growth. It is difficult to ascribe any definitive reasons why states might do this, but two contributors might be (a) physicians are trying to ensure future contracts or (b) legislators are reacting to consumers' fears about managed care. It is interesting to note that all the Southern states that passed either $\mathrm{OB} / \mathrm{GYN}$ regulation had very low $\mathrm{HMO}$ penetration (ranging from 0.9 percent to 19.1 percent in 1996). ${ }^{43}$

This study identified some areas for future research. First, researchers should test other managed care regulations within the framework of regulatory choice. Second, work should be done to improve model specification. Data on campaign contributions and lobbying intensity, for instance, would certainly help to define actual interest group pressure. A political variable that might strengthen the model is public opinion. Managed care regulation is a contentious issue; it is reasonable to presume that public opinion impacts legislators. Again, better data would improve future studies. Finally, this study did not take into account the public interest theory of regulatory choice. Testing such a theory, which would require identifying market failures and politicians responses to market failures, is difficult. However, making this determination would prove a worthy task for future researchers.

Despite its limitations, this study found that the theories of regulatory choice do help to explain why states pass regulations. It identified the importance of interest groups, policy entrepreneurs, and political party control of government as important factors in the legislative process. Also, the study demonstrated that singular theories of regulation cannot alone account for the presence of laws; the policymaking process incorporates aspects of both the political and economic theories.

\section{Notes}

I would like to acknowledge helpful comments and suggestions from Professor Lori Brainard, Thomas Catlaw, and Bettina Lanyi. Also, I would like to thank Dr. Herb Wong of the Agency for Health Care Policy and Research, who provided the data for this project.

'Gail Jensen, et al., "The New Dominance of Managed Care: Insurance Trends in the 1990s," Health Affairs 16 (1997): 125-136.

${ }^{2}$ Robert Blendon, et al., "Understanding the Managed Care Backlash," Health Affairs 17 (1998): 83.

${ }^{3}$ James P. Pfiffner, "President Clinton and the 103d Congress: Winning Battles and Losing Wars," in Rivals for Power: Presidential-Congressional Relations, ed. James Thurber (Washington, DC: Congressional Quarterly Inc., 1990, 180-181.

${ }^{4}$ Robert B. Hackey, Rethinking Health Care Policy; The New Politics of State Regulation (Washington, DC: Georgetown University Press, 1998), 1-2; Tracy E. Miller, "Managed Care Regulation: In the Laboratory of the States," Journal of the American Medical Association, 278 (1997): 1102.

5 Thomas Bodenheimer, "The HMO Backlash - Righteous or Reactionary?" The New England Journal of Medicine 21 (1996): 1601.

"Robert L. Ohsfeldt, et al., "The Spread of Any Willing Provider Laws," Health Services Research 33, Part II (1998): 1537-1562.

7 Gary S. Becker, "A Theory of Competition Among Pressure Groups for Political Influence," Quarterly Journal of Economics 93 (1983): 371-400.

${ }^{8}$ In an article criticizing the economic theory of regulation, Paul Quirk nored: "Effors should be made to put the economic theory and one such as ours [political theory] to rigorous comparative tests. Tests of economic theories have generally measured, for example, whether interest groups have some influence rather than none. Such tests are not pertinent to choosing between the two theories." Paul J. Quirk, "In Defense of the Politics of Ideas," The Journal of Politics 50 (1988): 40.

"David Vogel, "The 'New' Social Regulation in Historical and Comparative Perspective," in Regulation in Perspective: Historical Essays, ed. Thomas McCraw (Cambridge, MA: Harvard University Press, 1981), 238. 
17 Stephen Breyer, Regulation and Its Reform (Cambridge, MA: Harvard University Press, 1982), 16.

"Mark V. Pauly, "The Economics of Moral Hazard," American Economic Review 58 (1968): 533-534.

${ }^{12}$ Roger B. Feldman, Douglas R. Wholey, and Jon B. Christianson, "HMO Consolidations: How National Mergers Affect Local Markets," Health Affairs (1999): 99.

${ }^{13}$ Deborah Haas-Wilson and Marcin Gaynor, "Increasing Consolidation in Healthcare Markets: What are the Antitrust Implications?" Health Services Research Part II (1998): 1403.

${ }^{14}$ Vogel, 238.

"Lori A. Brainard, The Limits of Deregulation: The Politics of Television Policy, Ph.D. Dissertation, Brandeis University (1998), 5.

16 The 1974 Employee Retirement Income Security Act (ERISA) exempts health insurance companies from state regulations relating to employee benefit plans. The exemption was initially granted for fear that the cost of providing health insurance would skyrocker if consumers were allowed to sue health insurers.

17 Jill A. Marsteller and Randall R. Bovbjerg, "Federalism and Patient Protection: Changing Roles for State and Federal Government," The Urban Institute series Assessing the New Federalism, Number 28, August 1999 <www.urban.org>.

${ }^{18}$ Molly Stauffer and Elizabeth Kaiser, "Women's Health: A Legislative Overview of Selected Mandates," Health Policy Tracking Service, National Conference of State Legislatures (1999): 2-4.

19 Kenneth ]. Arrow, "Uncertainty and the Welfare Economics of Medical Care," American Economic Review 53 (1963): 948-954.

${ }^{20}$ George Stigler, "The Theory of Economic Regulation," Bell Journal of Economics and Management Science 2 (1971): 109-148.

21 Sam Peltzman, "Toward A More General Theory of Regulation," Journal of Law and Economics 19 (1976): 109-148.

${ }^{22}$ Mancur Olsen, The Rise and Decline of Nations: Economic Growth, Stagflation, and Social Rigidities (New Haven, CT: Yale University Press, 1982), 18-25.

${ }^{2.3}$ Brainard, 11.

${ }^{24}$ Martha Derthick and Paul J. Quirk, The Politics of Deregulation (Washington, DC: The Brookings Institute, 1985), 237-246.

${ }^{25}$ James Q. Wilson, The Politics of Regulation (New York: Basic Books, 1980), 370.

${ }^{26}$ Stauffer and Kaiser, 4.

${ }^{27}$ The regulation allowing women to designate an OB/GYN as a primary care physician was not analyzed separately for two reasons. First, as Dr. Robert Yelverton, chairman of the American College of Obstetricians and Gynecologists' primary care committee, said in a New York Tiness interview, "the vast majority of OB/GYNs have opted to remain as specialists rather than act as primary care physicians"; Larry Katzenstein,
"Beyond the Horror Stories, Good News about Managed Care," The New York Times (13 June 1999). Second, a study conducted by Bartman et al. found little cose difference between $O B / G Y N$ serving as primary care physicians and traditional primary care physicians. For these reasons, it is assumed that managed care firms would not stridently oppose this regulation; Barbara Bartman, et al., "Cost Differences Among Women's Primary Care Physicians," Health Affairs 15 (1996): 177.

${ }^{28}$ The legislative process is not instantaneous. It is unrealistic to expect that bills are introduced, debated, voted on, and signed all within the same year:

${ }^{29}$ Ohsfeldt et al., 1547.

${ }^{30}$ For this model, primary care physicians are defined as general/family practice, pediatrics, and general internal medicine.

${ }^{31}$ Ohsfeldt et al., 1538.

32 Charles E. Phelps, Health Economics, 2d ed. (Reading, MA: AddisonWesley, 1997), 389-392.

3.3 Helen Dewar and Amy Goldstein, "Measures on Patients' Rights Lose in Senate," The Washington Post (14 July 1999).

${ }^{34}$ Nebraska has a non-partisan, unicameral legislature. It is assumed that the party of the governor indicates the control of the government.

${ }^{35}$ John Kingdon, Agendas, Alternatives, and Public Policies, $2 \mathrm{~d}$ ed. (New York: Harper-Collins, 1995).

${ }^{36}$ Eugene Declercq and Diana Simmes, "The Polities of 'Drive-Through Deliveries': Putting Early Postpartum Discharge on the Legislative Agenda," The Milibank Quatterly75 (1997): 191.

37 For an example of this literature, see Karen Kaufmann and John Petrocik, "The Changing Politics of American Men: Understanding the Sources of the Gender Gap," American Joumal of Political Science 43 (1999).

${ }^{38}$ One important assumption of ordinary least squares regression is that the disturbance terms $\left(e_{i}\right)$ have equal variances - that is, the variances are homoscedastic. This assumption is violated in instances when the dependent variable is binary. Logistic regression is, thus, a more appropriate technique. Damor N. Gujarati, Basic Econometrics, 3d ed. (New York: McGraw-Hill, 1995), 543-544.

39 Since logistic coefficients are difficult to interpret, it is helpful to examine the substantive effect of the explanatory variables by estimating the percent change in the odds for a one-unit change in each significant predictor. Logistic output provides the log odds for each one-unit change (holding all other variables constant). The estimated percent change in the odds for a one-unit increase in the predictor is calculated as such: 100 $\left[\exp \left(\beta_{j}\right)-1\right]$, where $\beta_{i}$ is the coefficient of the predictor. Alfred DeMaris, Logit Modeling: Practical Applications, Sage University Paper series on Quantitative Applications in the Social Sciences, 07-086 (Newbury Park: CA: Sage, 1992), 46.

${ }^{40}$ This was confirmed through a telephone discussion with a representative of this organization.

11 Robert M. Goldberg, "Why HMOs Now Love Regulation," The Wall Street Joutrnal (17 July 1998). 
42 Jill A. Marsteller, et al., "The Resurgence of Selective Contracting Restrictions," Journal of Health Politics, Policy and Law 22 (1997), 1165.

43 Alabama, Arkansas, Louisiana, Missouri, North Carolina, and Texas were considered the Southern states. Missouri was the outlier with 19.1 percent HMO penetration. All the other states had figures in the single digits.

\section{Bibliography}

Arrow, Kenneth J. "Uncertainty and the Welfare Economics of Medical Care." Amertian Economic Review 53 (1963): 941.

Bartman, Barbara, et al. "Cost Differences Among Women's Primary Care Physicians." Health Affairs 53 (1996): 177.

Becker, Gary S. "A Theory of Competition Among Pressure Groups for Political Influence," Quarterly Journal of Economics (1983): 371.

Blendon, Robert, et al. "Understanding the Managed Care Backlash." Health Affairs 17 (1998): 80.

Bodenheimer, Thomas. "The HMO Backlash - Righteous or Reactionary?" The New England Journal of Medicine 21 (1996): 1601.

Brainard, Lori A. The Limits of Deregulation: The Politics of Television Policy. Ph.D. Dissertation, Brandeis University, 1998.

Breyer, Stephen. Regulation and Its Reform. Cambridge, MA: Harvard University Press, 1982.

Declercq, Eugene and Diana Simmes. "The Politics of 'Drive-Through Deliveries': Putting Early Postpartum Discharge on the Legislative Agenda." The Milbank Quarterly 75 (1997): 175.

DeMaris, Alfred. Logit Modeling: Practical Applications, Sage University Paper series on Quantitative Applications in the Social Sciences, 07-086. Newbury Park, CA: Sage, 1992.

Derthick, Martha and Paul J. Quirk. The Politics of Deregulation. Washington, DC: The Brookings Institute, 1985.

Dewar, Amy and Helen Goldstein. "Measures on Patients' Rights Lose in Senate." The Wrshington Post (14 July 1999).

Feldman, Roger, Douglas Wholey, and Jon Christianson. "HMO Consolidation; How National Mergers Affect Local Markets." Health Affairs 18 (1999): 96.

Goldberg, Robert. "Why HMOs Now Love Regulation." The Wall Street Joumal (17 July 1998).

Gujararti, Damodar N. Basic Econometrics, 3d ed. New York: McCraw-Hill, 1995.

Haas-Wilson, Deborah and Martin Gaynor. "Increasing Consolidation in Healthcare Markets: What are the Anticrust Implications?" Health Services Research 33 Part II (1998): 1403.

Hackey, Robert. Retbinking Health Care Policy: The Netw Politics of State Regulation. Washington, DC: Georgetown University Press, 1998.
Gail, Jensen, et al. "The New Dominance of Managed Care: Insurance Trends in the 1990s." Health Affairs 16 (1997): 125.

Katzenstein, Larry. "Beyond the Horror Stories, Good News About Managed Care." The New York Times (13 June 1999).

Kaufmann, Karen and John Petrocik. "The Changing Politics of American Men: Understanding the Sources of the Gender Gap." American Journal of Political Science 43 (1999): 864.

Kingdon, John. Agendas, Alternatives, and Public Policies. $2 \mathrm{~d}$ ed. New York: Harper-Collins, 1995.

Marsteller, Jill and Randall R. Bovbjerg. "Federalism and Patient Protection: Changing Roles for State and Federal Government." The Urban Institute series Assessing the New Federalism, Number 28. August 1999 <http://www.urban.org>.

Marsteller, Jill, et al. "The Resurgence of Selective Contracting Restrictions." Journal of Health Politics, Policy and Law 22 (1997): 1133.

Miller, Tracy E. "Managed Care Regulation: In the Laboratory of the States." Journal of the American MedicalAssociation 278 (1997): 1102.

Ohsfeldt, Roger, et al. "The Spread of Any Willing Provider Laws." Health Services Research 33 Part II (1998): 1537.

Olson, Mancur. The Rise and Decline of Nations: Economic Growth, Stagflation and Social Rigidities. New Haven, CN: Yale University Press, 1982.

Pauly, Mark V. "The Economics of Moral Hazard." American Economic Review 58 (1968): 531.

Peltzman, Sam. "Toward A More General Theory of Regulation." Journal of Law and Economics 19 (1976): 109.

Pfiffner, James P. "President Clinton and the 103d Cangress: Winning Battles and Losing Wars." In Rivals for Power: Presidential-Congressional Relations. Ed. James Thurber. Washington, DC: Congressional Quarterly, Inc, 1996.

Phe!ps, Charles C. Health Economics. 2d ed. Reading, MA: Addison-Wesley, 1997.

Quirk, Paul J. "In Defense of the Politics of Ideas." Journal of Politics 50 (1988): 31 .

StataCorp. Stata Statistical Software: Release 6.0. College Station, TX: Stata Corporation, 1999.

Stauffer, Molly and Elizabeth Kaiser, "Women's Health: A Legislative Overview of Selected Mandates." Health Policy Tracking Service, National Conference of Legislatures, 1999.

Stigler, George. "The Theory of Economic Regulation." Bell Journal of Economics and Management Science 2 (1971): 109.

Vogel, David. "The 'New' Social Regulation in Historical and Comparative Perspective," In Regulation in Perspective: Historical Essays. Ed. Thomas McCraw. Cambridge, MA: Harvard University Press, 1981. 
Wilson, James Q. The Politics of Regulation. New York: Basic Books, 1980. 
